\title{
The sensory acceptability of a tilapia (Oreochromis niloticus) mechanically separated meat-based spread
}

\author{
Aceitabilidade de patê à base de carne de tilápia \\ (Oreochromis niloticus) mecanicamente separada
}

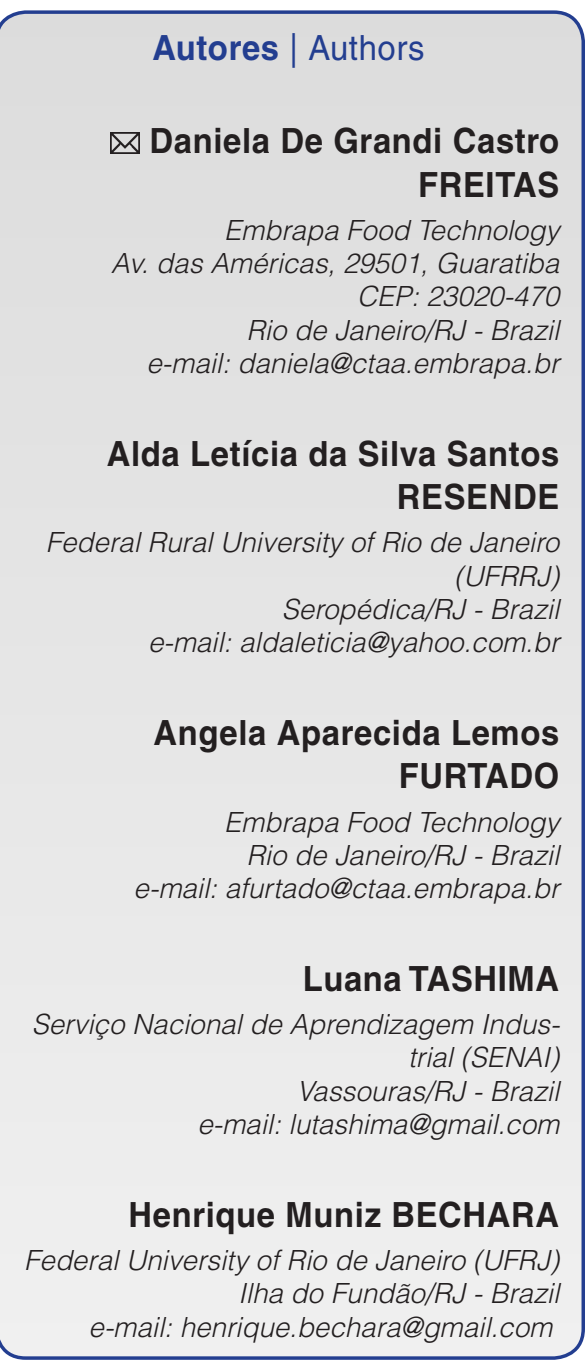

$\triangle$ Autor Correspondente / Corresponding Author

Recebido / Received: 15/03/2010 Aprovado / Approved: 05/12/2011 Publicado / Published: jun./2012

\section{Summary}

Mechanically Separated Meat (MSM) is an alternative for the diversification of new fish-based products and also as a solution for the use of waste from the filleting industries. Tilapia MSM was used in this study for the formulation of a fish spread aimed at investigating its acceptability by consumers. Two spread formulations were prepared with different types of commercial salt: seasoned salt (A) and common salt (B). The consumers (112) evaluated their acceptance with respect to overall impression, spreadability, appearance and flavour acceptability on a 9-point hedonic scale. A microbiological analysis of the Tilapia MSM was also carried out and the chemical composition of the Tilapia MSM-based spread determined. When considering the acceptance of all the consumers, the overall impression, appearance and flavour were significantly $(P<0.05)$ lower for the spread made with common salt (B). However, three different consumer segments could be found from the overall impression of the Tilapia MSM-based spread. The largest segment also preferred the spread made with the seasoned salt $(A)$, but both products were well accepted. The tilapia MSM presented adequate quality as a raw material according to the technical regulations for microbiological standards. The final product presented the following chemical composition: moisture $-62.17 \%$; ash $-2.11 \%$; protein $-9.75 \%$ and lipid $-18.81 \%$. These results could be of great importance for the industry in developing and marketing new products obtained from mechanically separated Tilapia meat.

Key words: Acceptability; Consumers; Mechanically separated meat; Tilapia.

\section{Resumo}

A carne mecanicamente separada (CMS) é uma alternativa para a diversificação de novos produtos à base de pescado e também se mostra como um destino para os resíduos da indústria de filetagem. A carne mecanicamente separada de tilápia foi utilizada, neste estudo, na formulação de patê, com o objetivo de investigar a aceitabilidade desse produto pelos consumidores. Duas formulações de patê foram preparadas, com diferentes tipos de sais comerciais: sal temperado (A) e sal comum (B). Consumidores (112) avaliaram a aceitação em relação à impressão global, à espalhabilidade, à aparência e ao sabor em escala hedônica de nove pontos. A análise microbiológica da carne mecanicamente separada de tilápia e a composição química da formulação de patê de tilápia também foram determinadas. Quando a aceitação de todos os consumidores foi considerada, a impressão global, a aparência e o sabor foram significativamente $(p<0,05)$ inferiores para o patê de tilápia com sal comum (B). No entanto, três diferentes grupos de consumidores foram encontrados a partir da aceitabilidade da impressão global do patê de tilápia. O maior segmento também preferiu o patê de tilápia com sal temperado (A), mas ambos tiveram alta aceitabilidade. A CMS de tilápia apresentou qualidade como matéria-prima de acordo com regulamento técnico sobre padrões microbiológicos. O produto final apresentou a seguinte composição química: umidade - 62,17\%; cinzas - 2,11\%; proteína - 9,75\%, e lipídios - 18,81\%. Esses resultados podem ser de grande importância para a indústria no desenvolvimento e na comercialização de novos produtos obtidos a partir da carne mecanicamente separada de tilápia.

Palavras-chave: Aceitabilidade; Consumidores; Carne mecanicamente separada; Tilápia. 


\section{Introduction}

Global aquaculture production has increased over the past fifty years, from less than 1 million $t$ in the early 50 's, to 59.4 million $\mathrm{t}$ in 2004 . According to FAO estimates (2007), an additional 40 million $t$ of fish will be required by 2030 just to meet the current levels of consumption. Kourous (2007) reported that in the last twenty-five years aquaculture has been one of the food production sectors which grew more throughout the world, with an annual increase of $8.8 \%$ since 1970 . Currently, about $45 \%$ of all fish for human consumption comes from farms.

In Brazil, the total aquaculture production was 289,000 t in 2007, the largest in history (BRASIL, 2007). Aquaculture is a promising activity, registering growth above the world average, from 278,000 $t$ in 2003 to 415,000 t in 2009 , with a $60.2 \%$ growth in fish production between 2007 and 2009. The production of Tilapia alone increased $105 \%$ in seven years (2003-2009) (BRASIL, 2011). According to Costa (2006), in Brazil the aquaculture and fisheries sector has a financial movement of 31 billion reais $(R \$)$ a year throughout the whole production chain, equivalent to $1.6 \%$ of the country's economy. One of the biggest challenges these companies face at present is to seek alternative raw materials, since the supplies of tuna and sardines depend solely on fishing, since these species cannot be bred in captivity.

According to the Ministry of Fisheries and Aquaculture, Brazil has $12 \%$ of the entire reserves of available fresh water on the planet, with a coastline of more than 8 thousand $\mathrm{km}$ and more than 2 million ha of flooded land, reservoirs and estuaries. However, despite all this potential, Brazilians only consume $9.03 \mathrm{~kg}$ of fish per year, when the rate recommended by the World Health Organization (WHO) is $12 \mathrm{~kg} /$ capita.year $^{-1}$. To remedy this, the secretariat intends to take advantage of all this potential by a series of actions that will make fish more accessible to Brazilians, including the National Campaign to encourage the consumption of fish. The objectives of this campaign are: to increase the consumption of fish in the country, to promote healthier foods, to create jobs and increase the income of thousands of fishermen and fish producers in Brazil, and to inform the population about the quality and variety of Brazilian fish, the need to demand quality when purchasing fish and the importance of fish for the health. Fish inclusion in the child's diet is being encouraged to promote changes in the habit of consumption in the Brazilian population. The Ministry of Fisheries and Aquaculture is developing an Internet search, since March, 2012, with nutritionists and technicians responsible for school meals in public schools. The survey will result in the inclusion of fish in the diet of children and young people, and help to understand the problems that prevent or hinder the provision of this food during meals. The Federal Government's goal is to develop, after a diagnosis of the sector, well-defined public policies that encourage the early consumption of fish by young people. (BRASIL, 2012).

The production of Tilapia worldwide is being intensified, mainly due to the decline in marine fisheries and to the quality of its meat. Tilapia, one of the fish species most suitable for intensive farming and trade, has characteristics preferred by the market, such as white meat, firm texture, delicate taste, easy filleting, no " $Y$ " - shaped bones, in addition to productive characteristics suitable for breeding: high growth rate and adaptability to different conditions (JORY et al., 2000).

About $70 \%$ of the carcass is residue in the processing of Tilapia meat. In Brazil, this residue is being widely used to produce animal feed (PESSATTI, 2001). The Mechanically Separated Meat (MSM), parts of the fillet obtained due to standardization of the format in the filleting process, is an alternative for the diversification of new fish products and uses the filleting waste from the industry (SIMÕES et al., 2004). After obtaining the fillets, the main product of the Tilapia culture, a considerable quantity of meat remained attached to the skeleton. The minced fish obtained from the machine (about 14\% by weight of the live Tilapia) can be used in the manufacture of other products with greater added value. The authors reported that the recovery of attached meat can reach $60 \%$ of the material passing through the machine.

In Brazil, the use of fish waste is small, with approximately $50 \%$ of the biomass being discarded during the canning process or that of other production lines, such as filleting (PESSATTI, 2001). According to a market research study carried out by SEBRAE (2008), most producers extract and sell the fillet for a good price, but the large amount of waste results in a considerable loss in productivity, since it corresponds to about $40 \%$ of the carcass of this fish. The waste is sold for feed production or fish meal with low profitability.

The spread made from the material rejected during Tilapia filleting could promote waste recovery and diversification by the industry. Rivera (1994) elaborated a tuna spread by subjecting the waste to a mechanical meat-bone separator, obtaining ground meat for use as a raw material. After testing different formulations and the addition of various spices, a final product was obtained with an output of approximately $90 \%$ and similar to those available on the market.

Minozzo (2005) developed a creamy spread from Tilapia fillets and carried out a physical, chemical, microbiological and sensory characterization, obtaining formulations that conformed to the legal specifications and were well accepted on the consumer market.

Aquerreta et al. (2002) developed three types of fish spreads, manufactured with different quantities 
The sensory acceptability of a tilapia (Oreochromis niloticus) mechanically separated meat-based spread FREITAS, D. G. C. et al.

of tuna liver (Thunnus thynnus) and mackerel flesh (Scomber scombrus) in order to find a use for these low-cost raw materials. Their nutritional values were compared with commercial fish spreads made from tuna, large-scaled scorpion fish (Scorpaena scrofa), salmon (Salmo salar) and anchovy (Eugraulis encrasicholus). The commercial products showed higher omega-6/ omega-3 ratios, due to the lower contents of EPA and $\mathrm{DHA}$ and higher linoleic acid content, as a result of the addition of vegetable oils in this type of product. Although a strong fishy taste was detected in the sensory analysis of the experimental spreads, all of them were considered acceptable.

Marengoni et al. (2009) evaluated the microbiological, sensory and proximate composition characteristics of four experimental fish burgers prepared with mechanically separated Tilapia meat (Tilapia MSM) and all the formulations were moderately to well accepted. The results for purchase intention varied between "maybe buy, maybe not buy" and "probably buy" the product, showing that the use of fish processing by-products is a means of adding value to a final product, with good consumer acceptance and adequate quality standards.

Since the products obtained can be considered as new, an assessment of their acceptance by potential consumers is recommended. The aim of the present study was to assess the acceptability of a spread obtained from mechanically separated Tilapia meat, in order to produce a product with greater added value and promote waste recovery and diversification by the fish industry.

\section{Material and methods}

\subsection{Sample preparation}

Tilapia MSM was obtained from a cooperative of producers in Cachoeiras de Macacu - RJ, Brazil, and transported frozen to Embrapa Food Technology where it was stored frozen at $-18^{\circ} \mathrm{C}$. Two spread formulations were prepared with different commercial salts: $(A)$ seasoned salt (Temperart Ind. Com. Ltda., São Paulo/SP, Brazil) and (B) common salt, as shown in Table 1.

The components present in the seasoned salt were: salt, sugar, corn starch, pepper, spices, dehydrated vegetables, monosodium glutamate, maltodextrin,

Table 1. Tilapia MSM-based spread formulations.

\begin{tabular}{lcc}
$\begin{array}{c}\text { Ingredients } \\
(\%)\end{array}$ & $\begin{array}{c}\text { Common } \\
\text { salt spread }\end{array}$ & $\begin{array}{c}\text { Seasoned } \\
\text { salt spread }\end{array}$ \\
\hline Tilapia MSM & 60.0 & 60.0 \\
Seasoned salt & - & 1.1 \\
Pure salt & 1.6 & 0.5 \\
Other ingredients & 38.4 & 38.4 \\
(water, oil, starch) & & \\
\hline
\end{tabular}

vegetable fat, yeast extract, hydrolyzed vegetable protein, anti-caking agent, fish and shrimp flavour and natural dye.

After homogenization of the ingredients in a cutter, the paste was filled into aluminium cans (180 g capacity and dimensions of $80 \mathrm{~mm}$ diameter $\times 36 \mathrm{~mm}$ height), and submitted to heat processing in an autoclave. The cans were sealed and autoclaved and treated with a time/temperature binomial of $115^{\circ} \mathrm{C}$ for 15 minutes, adequate to sterilize the product, resulting in a F0 value of 7.14 minutes. Figure 1 outlines the processing steps of the tilapia MSM-based spread.

After processing, the Tilapia MSM-based spreads were stored at room temperature until analysed.

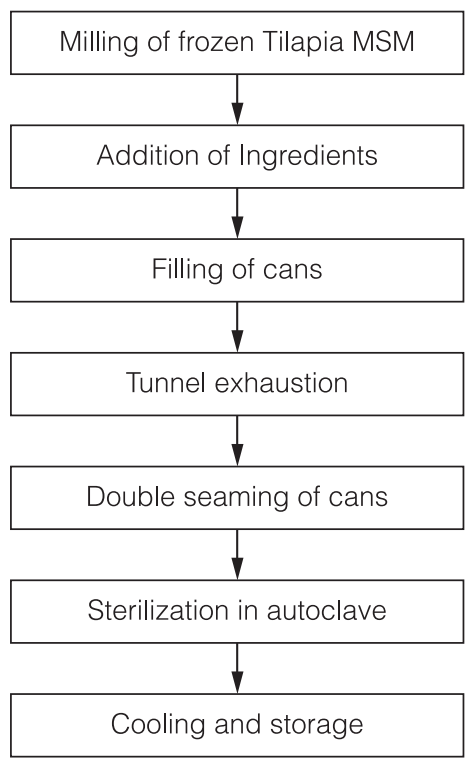

Figure 1. Processing flow chart of Tilapia MSM-based spread.

\subsection{Characterization of the spreads}

The chemical composition of the product was determined as follows: moisture content according to the AOAC (HORWITZ, 2000) method $n^{\circ}$ 952.08; ash content according to the AOAC (HORWITZ, 2000) method $n^{\circ}$ 923.03; ether extract according to the AOAC (HORWITZ, 2000) method $n^{\circ} 922.06$ and total nitrogen content according to the modified AACC (1995) method n 46-13. The microbiological analyses carried out on the Tilapia MSM included the counts of total coliforms at $45^{\circ} \mathrm{C}$, positive coagulase Staphylococcus and Salmonella spp., according to the method referred to in Brasil (2001).

\subsection{Consumer evaluation}

The consumer test was carried out at Embrapa Food Technology, Rio de Janeiro, Brazil. One hundred and twelve (112) consumers were selected according to their frequency of consuming fish meat products. 
The sensory acceptability of a tilapia (Oreochromis niloticus) mechanically separated meat-based spread

FREITAS, D. G. C. et al.

The two Tilapia MSM-based spreads were presented following a design to reduce the effects of the order of presentation and first order carry-over effects. The consumers evaluated overall impression, spreadability, appearance and flavour acceptability on 9-point hedonic scales, where: 1-disliked extremely; 5-neither liked nor disliked; 9-liked extremely. The samples were served in $30 \mathrm{~g}$ portions with a slice of toast, and the consumers instructed to pass the spread on the toast using the knife before tasting. The session was carried out in individual booths illuminated by white light.

\subsection{Statistical analysis}

According to the overall acceptability scores, the consumers were classified into different clusters using the Euclidean distances and Ward's aggregation method to segment assessors. The Euclidean distance is the geometric distance between two objects (or cases). Ward's method joins the cases into clusters, such that the variance within a cluster is minimised. Dissimilarity coefficients were used to measure the degree of similarity between the different scores obtained for the variables and adjusted linking scores were used for clustering purposes. The number of segments was determined by carrying out a visual assessment of the dendrogram and non-adjusted data were used to report average scores for liking, resulting from the preference segments. Within the segment and the total group, significant differences amongst the samples were assessed using ANOVA $(P<0.05)$ with the software Statistica v.7 (STATSOFT, 2007).

\section{Results and discussion}

The microbiological analysis of the tilapia MSM showed that the quality of the raw material used conformed to the technical regulations for the microbiological standards of products made from chilled or frozen fish: maximum of $10^{3} \mathrm{MPN} \cdot \mathrm{g}^{-1}$ (most probable number/gram) for total coliforms at $45^{\circ} \mathrm{C}$, and $10^{3} \mathrm{CFU} . \mathrm{g}^{-1}$ (colony forming units/gram) for coagulase positive Staphylococcus; and the absence of Salmonella ssp. in $25 \mathrm{~g}$ of product (Table 2). The sensory analysis was carried out one day after processing the spreads, ensuring a safe condition for the participants.

The chemical composition of the Tilapia MSM-based spread is shown in Table 3.

According to the Brazilian identity and quality technical regulations (BRASIL, 2000), 'paste' or 'spread' means an industrialized meat product obtained from the meat and/or meat products and/or edible giblets from different animal species obtained from butchers, processed into a pulp with the addition of other ingredients, and subjected to an appropriate heat treatment. The ingredients required are the meat and/or its
Table 2. Microbiological analysis of the Tilapia MSM.

\begin{tabular}{lc} 
Total coliforms at $45^{\circ} \mathrm{C}\left(\mathrm{MPN} . \mathrm{g}^{-1}\right)$ & Tilapia MSM \\
Salmonella ssp. (absence in $25 \mathrm{~g})$ & $<3.0$ \\
Coagulase positive Staphylococcus sp. & $<10^{2}$ \\
$\left(\mathrm{CFU} . \mathrm{g}^{-1}\right)$ & \\
\hline
\end{tabular}

Table 3. Chemical composition of the Tilapia MSM-based spread formulation.

\begin{tabular}{lc} 
& Content $\left(\mathbf{g} . \mathbf{1 0 0} \mathbf{~ g}^{-1}\right)$ \\
Moisture & $62.17(1.37)$ \\
Ash & $2.11(0.12)$ \\
Ether extract & $18.81(0.52)$ \\
Total nitrogen & $1.56(0.02)$ \\
Protein* & $9.75(0.12)$ \\
Carbohydrates ** $^{*}$ & 7.16 \\
\hline
\end{tabular}

*Obtained by multiplying the total nitrogen content by 6.25 . ${ }^{*}$ Obtained by subtraction ( 100 - moisture - ether extract - protein - ash). The data represent the mean of two replicates (estimate of the standard deviation).

giblets, salt, nitrite and/or sodium nitrate and/or potassium nitrate. However products designated with a specific name must contain at least $30 \%$ of the designated raw material, except in the case of liver, where the threshold may be $20 \%$. Optional ingredients can be incorporated, such as vegetable-origin proteins, sugars, maltodextrins, starch, condiments, spices and flavourings, amongst others. The chemical composition can contain a maximum of $10 \%$ starch; $10 \%$ total carbohydrates; $70 \%$ moisture; 32\% fat; and a minimum of $8 \%$ of protein.

The final formulation of the spread presented relevant contents of ash $\left(2.11 \mathrm{~g} .100 \mathrm{~g}^{-1}\right)$ and lipids

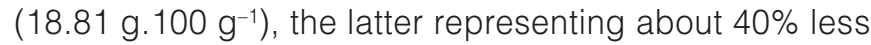
fat than the amount allowed by the Brazilian regulations.

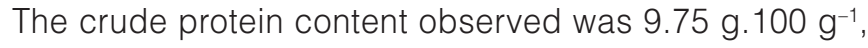
slightly above the regulated minimum percentage. With respect to the carbohydrate $\left(7.16 \mathrm{~g} .100 \mathrm{~g}^{-1}\right)$ and moisture (62.17 g.100 g $\mathrm{g}^{-1}$ ) contents, the tilapia MSM-based spread was within the limits imposed by the current legislation.

Minozzo et al. (2008) used mechanically separated Tilapia meat for the production of creamy and pasty spreads. The Tilapia spreads were submitted to a chemical analysis, obtaining the following values: moisture 58.03 and $56.78 \%$, ash 3.26 and $3.01 \%$, protein 8.77 and $9.69 \%$, lipid 26.12 and $28.15 \%$ and carbohydrates 3.83 and $2.37 \%$, respectively. These values are similar to those found in the present study, except for the levels of lipids and proteins, which were lower for proteins and higer for lipids.

Minozzo et al. (2004) developed and characterized a Tilapia fillet spread and compared it to similar products. The Tilapia spread and two trademark spreads, namely tuna spread and ham spread, were subjected to a 
The sensory acceptability of a tilapia (Oreochromis niloticus) mechanically separated meat-based spread

FREITAS, D. G. C. et al.

chemical analysis for moisture, ash, protein, lipid and carbohydrates. The Tilapia spread had a higher lipid content (27.41 $\mathrm{g} .100 \mathrm{~g}^{-1}$ ) and higher calorific value than the trademark spreads. The ash content found was $2.20 \mathrm{~g} .100 \mathrm{~g}^{-1}$ and the protein content was $8.53 \mathrm{~g} .100 \mathrm{~g}^{-1}$. The results also showed that the Tilapia spread had a chemical composition conforming to the standards set by the Brazilian legislation. Marengoni et al. (2009) also studied different formulations of fish burgers prepared with mechanically separated Tilapia meat, obtaining the following results in physicalchemical analysis: 15.50 to $16.14 \mathrm{~g} .100 \mathrm{~g}^{-1}$ of crude protein, 1.73 to $10.28 \mathrm{~g} .100 \mathrm{~g}^{-1}$ of ether extract and

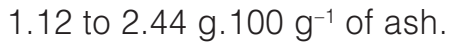

Minozzo et al. (2002) claimed that the fish, besides being a protein rich food, contained essential amino acids that were also highly digestible. For these authors, knowledge of the chemical composition of a fish is of great importance in the preparation of diets, in the choice of an adequate conservation process and consequently in the quality control of the final product. These authors evaluated the chemical composition of frozen or cooled Tilapia fillet and found, on average, $11.88 \%$ of crude protein and $2.19 \%$ of total minerals. Leonhardt et al. (2006) evaluated the morphometric characteristics, yield and composition of Nile Tilapia fillet and found $18.48 \%$ of crude protein, $2.96 \%$ of lipids and $1.41 \%$ of ash. The lipid contents ranged from 0.59 to $0.99 \%$ in a study for the characterization of the total lipids of Tilapia carried out by Vila Nova et al. (2005). The authors concluded that even under different conditions, Tilapia meat had an excellent nutritional quality.

Figure 2 shows the frequency of acceptance (scores between 6.0 and 9.0) and of rejection (scores between 1.0 and 4.0) for the Tilapia MSM-based spreads. The average scores for consumer acceptability are shown in Table 4

A larger number of consumers showed greater acceptance of the sample formulated with seasoned salt (A) with respect to the attributes of overall impression, spreadability and appearance. With respect to flavour the two formulations showed the same frequency of acceptance. The results showed that, even for spreadability, where there was no significant difference between the average scores, there was a higher percentage of scores within the region of rejection for the spread formulated with common salt (B). The scores for overall impression were 7.56 and 6.99 for the spreads formulated with seasoned (A) and common (b) salt, respectively.

Minozzo et al. (2008) evaluated the use of mechanically separated Tilapia meat for the production of creamy and pasty Tilapia spreads. The creamy $(65 \%$ cooked Tilapia MSM and 35\% raw Tilapia MSM) and pasty
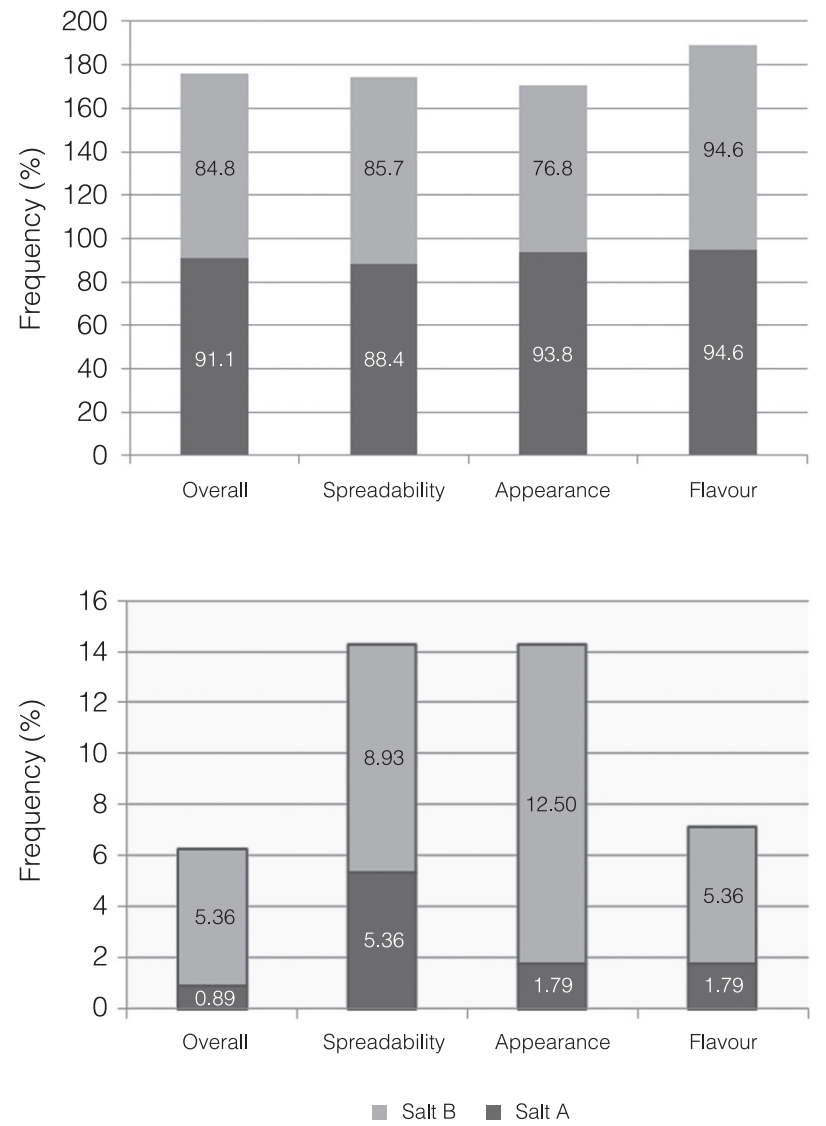

Figure 2. Frequency of acceptance (a) and rejection (b) scores in the consumer data.

Table 4. Consumer scores obtained for overall impression, spreadability, appearance and flavour for the two formulations of Tilapia MSM-based spread (A: seasoned salt, B: common salt).

\begin{tabular}{lrrc} 
& $\mathbf{n}$ & $\mathbf{A}$ & $\mathbf{B}$ \\
\hline $\begin{array}{l}\text { Overall impression } \\
\quad \text { Total }\end{array}$ & 112 & $7.56^{\mathrm{a}}$ & $6.99^{\mathrm{b}}$ \\
$\quad$ Cluster 1 & 41 & $7.65^{\mathrm{a}}$ & $6.56^{\mathrm{b}}$ \\
$\quad$ Cluster 2 & 44 & $8.68^{\mathrm{a}}$ & $8.29^{\mathrm{b}}$ \\
$\quad$ Cluster 3 & 27 & $5.59^{\mathrm{a}}$ & $5.51^{\mathrm{a}}$ \\
$\begin{array}{l}\text { Spreadability } \\
\quad \text { Total }\end{array}$ & 112 & $7.41^{\mathrm{a}}$ & $7.32^{\mathrm{a}}$ \\
$\begin{array}{l}\text { Appearance } \\
\quad \text { Total }\end{array}$ & 112 & $7.61^{\mathrm{a}}$ & $6.69^{\mathrm{b}}$ \\
$\begin{array}{l}\text { Flavour } \\
\text { Total }\end{array}$ & & & \\
\hline
\end{tabular}

Different superscripts in the same line indicate significant $(p<0.05)$ differences.

(100\% cooked Tilapia MSM) spreads were submitted to an acceptability test carried out by consumers using 9-point hedonic scales. The sensory acceptability was higher for the creamy spread, with an average of 7.40 .

Marengoni et al. (2009) evaluated the sensory acceptance of four experimental fish burgers prepared with mechanically separated Tilapia meat. The untrained panellists (43) scored for overall appearance, odour, 
flavour and texture acceptability on 9-point hedonic scales, and purchase intention was evaluated on a 5-point structured scale. The results showed there was no preference between the experimental fish burgers. For all the attributes evaluated, there was no significant difference between the scores given to the samples, with average scores varying from 7.14 to 7.46 . In general, the subjects moderately liked the products, and the results related to purchase intention varied between "maybe buy, maybe not buy" and "probably buy" the product. Aquerreta et al. (2002) evaluated the overall acceptability of fish spreads manufactured with tuna liver and mackerel flesh using a six-point scale from (1) very disagreeable to (6) very agreeable. Different percentages of raw materials were used in the three formulations: 10:30 (A), 10:35 (B) and 20:30 (C) (tuna liver:mackerel flesh). A quantitative descriptive analysis (QDA) was also carried out to evaluate the sensory characteristics of the formulations. The samples were examined by 10 selected and trained panellists for: fishy odour, fishy taste, fattiness and granularity. A continuous scale between 1 and 6 was used. In general, the fishy odour and taste were considered as "strong", especially in product C, which had the highest percentage of fish liver. With respect to the texture properties, product $A$, which had a greater level of pork back fat, was more suitable for spreading. Product A showed the highest acceptability, although all of them were considered acceptable.

These results show the good acceptance of fish spreads by the consumer and of products elaborated from Tilapia MSM, although studies with a larger number of subjects and appropriate hedonic scales should be carried out.

The Cluster Analysis is a way of grouping data based on the similarity of the responses to several variables. In the present case, the aim was to better interpret the consumer preference data in order to identify consumer groups according to the similarity of their individual responses. After carrying out a cluster analysis on the overall acceptability data for the Tilapia MSM-based spreads, three different segments were identified in the dendrogram, as shown in Figure 3.

When all the consumers were considered, the overall impression, appearance and flavour acceptability were significantly lower for sample $\mathrm{B}$, indicating consumer preference for the spread formulated with seasoned salt. The flavour was improved by the condiments, probably the monosodium glutamate, vegetable fat, yeast extract, hydrolyzed vegetable protein and fish flavours; but the attribute appearance showed the biggest difference. The presence of the condiments and dye enhanced the colour of the spread according to the consumers' comments. For spreading, there was no significant difference in the acceptability scores for the samples.

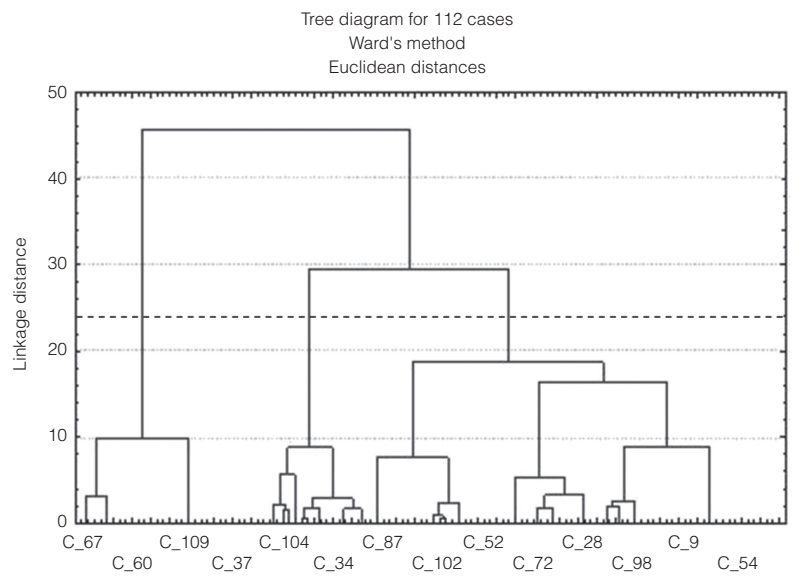

Figure 3. Dendrogram for the overall acceptability of two samples of Tilapia MSM-based spreads.

Overall, the consumers moderately liked spread A, which was preferred as compared to spread B.

When the consumers were segmented according to their overall acceptability, three different clusters of consumers were detected. The consumers from cluster $1(n=41)$ preferred spread $A$ to spread $B$, presenting similar acceptability scores to the whole consumer group. The second cluster of consumers, the biggest ( $n=44)$, was similar to the previous one, but showed higher scores for the two samples. This group scored the products as "liked very much", also preferring spread A to spread B (with scores of 8.68 and 8.29, respectively). For the third cluster of consumers, the smallest $(n=27)$, no difference ( $p>0.05$ ) was detected between the acceptability of spreads A and B. Moreover, this consumer group was different from the other two groups, since they "neither liked nor disliked" the Tilapia MSM-based spreads.

The cluster analysis showed that the biggest segment of consumers liked both formulations very much. Nevertheless, a preference was observed for the Tilapia MSM-based spread formulated with seasoned salt. These findings indicate the feasibility of producing spreads using mechanically separated Tilapia meat, since the two formulations evaluated were well accepted by most consumers.

\section{Conclusions}

The spreads obtained from Tilapia MSM were well accepted by most consumers. In general, the consumers preferred the Tilapia MSM-based spread formulated with seasoned salt, mostly due to the improvement in its appearance and flavour. Nevertheless, different clusters of consumers could be observed from the acceptability of the spreads, showing different overall acceptability scores. The biggest segment of consumers liked the spread made with seasoned salt extremely, and liked the spread made with common salt very much. These findings 
The sensory acceptability of a tilapia (Oreochromis niloticus) mechanically separated meat-based spread FREITAS, D. G. C. et al.

could be of great importance for the fish industry in the development and marketing of new products obtained from Tilapia MSM.

\section{References}

AMERICAN ASSOCIATION OF CEREAL CHEMISTS - AACC. Approved methods of AACC. 9. ed. Sant Paul: AACC, 1995 v. 2, p. 1-2, method n. 46-13.

AQUERRETA, Y.; ASTIASARANA, I.; MOHINO, A.; BELLO, J. Composition of pâté elaborated with mackerel flesh (Scomber scombrus) and tuna liver (Thunnus thynnus): comparison with commercial fish pâté. Food Chemistry, Oxford, v. 77 , n. 2, p. 147-153. 2002. http://dx.doi.org/10.1016/S03088146(01)00310-7

BRASIL. Agência Nacional de Vigilância Sanitária - ANVISA. Resolução-RDC n 12, de 2 de janeiro de 2001. Regulamento Técnico sobre os padrões microbiológicos para alimentos. Diário Oficial da República Federativa do Brasil, Poder Executivo, Brasília, DF, 10. jan. 2001. 54 p.

BRASIL. Ministério da Pesca e Aquicultura. O potencial Brasileiro para Aqüicultura. 2011. Disponível em: <http://www. mpa.gov.br/\#aquicultura/informacoes/potencial-brasileiro>. Acesso em: 10 jun. 2011.

BRASIL. Ministério da Agricultura. Secretaria de Defesa Agropecuária. Departamento de Inspeção de Produtos de Origem Animal. Instrução Normativa n²1, de 31 de julho de 2000. Regulamentos Técnicos de Identidade e Qualidade de Patê, de Bacon ou Barriga Defumada e de Lombo Suíno. Diário Oficial da República Federativa do Brasil, Poder Executivo, Brasília, DF, 03 ago. 2000. Seção 1, v. 137, n. 149, p. 12-15.

BRASIL. Ministério da Pesca e Aquicultura. Secretarias de Educação Participam de Pesquisa sobre Consumo de Pescado nas Escolas. Brasília: Imprensa, 20 abr. 2012. Disponível em: <http://www.mpa.gov.br/index.php/imprensa/ noticias/508-secretarias-de-educacao-participam-de-pesquisasobre-consumo-de-pescado-nas-escolas>. Acesso em: 24 abr. 2012.

COSTA, M. O desafio de vender o peixe. Anuário Exame - Agronegócios, São Paulo, ed. 0869A, p. 114-115, jun. 2006.

FOOD AND AGRICULTURE ORGANIZATION OF THE UNITED NATIONS - FAO. Fisheries Department. La contribución de la acuicultura al desarrollo sostenible. In: CONFERENCIA, 2007, Roma. Proceedings... Roma: FAO, 2007. 11 p. Disponível em: <ftp://ftp.fao.org/docrep/fao/meeting/012/k0701s.pdf>. Acesso em: 14 maio 2012.

HORWITZ, W. (Ed.). Official Methods of Analysis of the Association of Official Analytica Chemists. 18. ed. Gaithersburg: AOAC, 2000.
BRASIL. Ministério do Meio Ambiente. Instituto Brasileiro do Meio Ambiente e dos Recursos Naturais Renováveis - IBAMA. Estatística da Pesca 2007: Brasil - Grandes Regiões e Unidades Federativas. Brasília: IBAMA, 2007. 113 p. Disponível em: <http://www.ibama.gov.br/documentos-recursospesqueiros/estatistica-pesqueira> . Acesso em: 14 maio 2012.

JORY, D. E.; ALCESTE, C.; CABRERA, T. R. Mercado y comercialización de Tilápia en los Estados Unidos de Norte América. Panorama Aquícola, Ciudad de México, v. 5, n. 5, p. 50-53, 2000.

KOUROUS, G. La Acuicultura: Única Forma de Hacer Frente al Futuro Déficit de Pescado. Roma: FAO, 19. nov. 2007. Sala de Prensa. Últimas noticias. Disponível em: <http://www.fao. org/newsroom/es/news/2007/1000701/index.html>. Acesso em: 05 mar. 2008.

LEONHARDT, J. H.; CAETANO FILHO, M.; FROSSARD, H.; MORENO, A. M. Características morfométricas, rendimento e composição do filé de Tilápia do Nilo, Oreochromis niloticus, da linhagem tailandesa, local e do cruzamento de ambas. Ciências Agrárias, Teresina, v. 27, n. 1, p. 125-132. 2006.

MARENGONI, N. G.; POZZA, M. S. S.; BRAGA, G. C.; LAZZERI, D. B.; CASTILHA, L. D.; BUENO, G. W.; PASQUETTI, T. J.; POLESE, C. Caracterização microbiológica, sensorial e centesimal de fishburgers de carne de Tilápia mecanicamente separada. Revista Brasileira de Saúde e Produção Animal, Salvador, v. 10, n. 1, p. 168-176. 2009.

MINOZZO, M. G. Elaboração de Patê Cremoso a Partir de File de Tilápia do Nilo (Oreochromis niloticus) e sua Caracterização Físico-Química, Microbiológica e Sensorial. 2005. 110 f. Dissertação (Mestrado em Ciência de Alimentos)Universidade Federal do Paraná, Curitiba, 2005. Disponível em: <http://hdl.handle.net/1884/1621>. Acesso em: 14 maio 2012.

MINOZZO, M. G.; VAZ, S. K.; GUBIANI, E. A.; JOHANN, A. P.; LAMPERTI, P. M.; MASSAGO, H.; BOSCOLO, W. Composição Química do Filé de Tilápia (Oreochromis niloticus), Submetidos ao Congelamento com e sem Glazeamento ou Resfriados. In: ENCONTRO ANUAL DE INICIAÇÃO CIENTÍFICA, 11., 2002. Maringá. Anais... Maringá: UEM, 2002. Disponível em: <http:// www.ppg.uem.br/Docs/pes/eaic/XI_EAIC/>. Acesso em: 14 maio 2012.

MINOZZO, M. G.; WASZCZYNSKYJ, N.; BEIRÃO, L. H. Características físico-químicas do patê de Tilápia do nilo (Oreochromis niloticus), comparado a produtos similares comerciais. Alimentos e Nutrição, Araraquara, v. 15, n. 2 , p. 101-105. 2004.

MINOZZO, M. G.; WASZCZYNSKYJ, N.; BOSCOLO, W. R. Utilização de carne mecanicamente separada de Tilápia (Oreochromis niloticus) para a produção de patês cremoso e pastoso. Alimentos e Nutrição, Araraquara, v. 19, n. 3, p. 315-319. 2008 
The sensory acceptability of a tilapia (Oreochromis niloticus) mechanically separated meat-based spread FREITAS, D. G. C. et al.

PESSATTI, M. L. (2001). Aproveitamento dos Subprodutos do Pescado. Ministério da Agricultura, Pecuária e Abastecimento, 2001. Meta 11. Relatório Final de Ações Prioritárias ao Desenvolvimento da Pesca e Aqüicultura no Sul do Brasil, Convênio Ministério da Agricultura, Pecuária e Abastecimento (MAPA), Universidade do Vale do Itajaí, MA/SARC, n. 003/2000.

RIVERA, M. J. G. N. Utilização de Resíduos da Indústria Pesqueira de Atum para Elaboração de Patê como um Produto Rentável. 1994. 97 f. Tese (Mestre em Ciência de Alimentos)Universidade Federal de Santa Catarina, Florianópolis, 1994

SEBRAE. Aquicultura e Pesca: Tilápias, Relatório Completo. Sebrae; ESPM, 2008. (Série Mercado, Estudos de Mercado Sebrae/ESPM, n. 8). Disponível em: <http://www.biblioteca. sebrae.com.br/bds/bds.nsf/77DBF2893A380B398325749E0 067E2C5/\$File/NT00038BEE.pdf>. Acesso em: 11 nov. 2008.
SIMÕES, D. R. S., QUEIROZ, M. I. VOLPATO, G., ZEPKA, L. Q. Desodorización de la base protéica de pescado (BPP) con ácido fosfórico. Revista Ciência Tecnologia de Alimentos, Campinas, v. 24, n. 1, p. 23-26, 2004. http://dx.doi.org/10.1590/ S0101-20612004000100005

STATSOFT. Electronic Statistics Textbook. Tulsa: StatSoft Inc., 2007.

VILA NOVA, C. M. V. M.; GODOY, H. T.; ALDRIGUE, M. L. Composição química, teor de colesterol e caracterização dos lipídios totais de Tilápia e pargo (Oreochromis niloticus) (Lutjanus purpureus). Revista Ciência e Tecnologia de Alimentos, Campinas, v. 25, n. 3, p. 430-436. 2005. http://dx.doi. org/10.1590/S0101-20612005000300007 